\title{
Media Pembelajaran Tematik Integratif Dengan Pendekatan IImiah Scientific Approach Untuk Siswa Kelas II Sekolah Dasar
}

\author{
Andini Putri Ayu Wulandari ${ }^{1}$, Syahbaniar Rofiah ${ }^{1, *}$ \\ *Korespondensi: e-mail: rsyahbaniar@gmail.com
}

\begin{abstract}
1 Program Studi Manajemen Informatika; Universitas Bina Insani; Jl. Siliwangi No.6 Rawa Panjang Bekasi Bekasi Timur 17114 Indonesia; Telp. (021) $82436886 /$ (021) 82436 996. Fax. (021) 824009 24; e-mail: andiniputriayu6@gmail.com, rsyahbaniar@gmail.com
\end{abstract}

Submitted: 12 Oktober 2020

Revised: 2 November 2020

Accepted: 16 November 2020

Published: 30 November 2020

\begin{abstract}
The development of increasingly sophisticated technology in the era of globalization today helps people in their lives is no exception to the world of education. Modernization not only touches on the realm of community life but on learning for Indonesian students. Learning done in schools is only done by direct or conventional practice whereas with modernization in learning, students should have used modern tools in learning lessons. The materials contained in many handbooks require more tangible visualization, not just text and images. One of the learning support tools is learning media, especially multimedia. Therefore, Integrative Thematic Learning Media with Scientific Scientific Approach at SDN Bekasi Jaya VIII is needed to use ADDIE (Analysis, Design, Development, Implementation and Evaluate) method to attract students in learning each material with interesting animation design.
\end{abstract}

Keywords: ADDIE, Learning Media, Scientific Approach, Thematic Integrative

Abstrak

Perkembangan teknologi semakin canggih di era globalisasi saat ini membantu manusia dalam kehidupannya tidak terkecuali dengan dunia pendidikan. Modernisasi bukan hanya menyentuh pada ranah kehidupan bermasyarakat namun pada pembelajaran bagi murid Indonesia. Pembelajaran yang dilakukan di sekolah hanya dilakukan dengan praktek langsung atau konvensional padahal dengan adanya modernisasi dalam pembelajaran seharusnya murid sudah menggunakan alat yang telah modern dalam mempelajari pelajaran. Materi-materi yang termuat dalam buku pegangan banyak yang membutuhkan visualisasi yang lebih nyata, bukan hanya dengan teks dan gambar. Salah satu alat pendukung pembelajarannya yaitu media pembelajaran, khususnya multimedia. Oleh karena itu dibutuhkan Media Pemelajaran Tematik Integratif dengan Pendekatan IImiah Scientific Approach pada SDN Bekasi Jaya VIII yang dalam pembuatannya menggunakan metode ADDIE (Analysis, Design, Development, Implementation and Evaluate) untuk menarik perhatian peserta didik dalam mempelajari setiap materi dengan desain animasi yang menarik.

Kata kunci: ADDIE, Media Pembelajaran, Scientific Approach, Tematik Integratif 


\section{Pendahuluan}

Perubahan kurikulum merupakan suatu hal yang biasa terjadi di Indonesia sejak dahulu. Salah satunya adalah perubahan dari KTSP menjadi Kurikulum 2013 yang sedang diterapkan saat ini. Kurikulum 2013 merupakan penyempurnaan dari kurikulum sebelumnya dengan tujuan meningkatkan mutu pendidikan di Indonesia. Pada Permendikbud No. 67 Tahun 2013 tentang Kurikulum SD, disebutkan bahwa penyempurnaan pada pola pikir yang dikembangkan. Semua penyempurnaan pola pemikiran yang telah disebutkan menitikberatkan pada perubahan dalam proses pembelajaran. Perubahan yang sangat mendasar pada proses pembelajaran adalah pembelajaran mata pelajaran menjadi pembelajaran tematik integratif dengan scientific approach dan penggunaan media tunggal menjadi multimedia Pendahuluan harus memberikan latar belakang yang jelas, pernyataan yang jelas dari masalah, literatur yang relevan pada subjek, pendekatan yang diusulkan atau solusi, dan nilai kebaruan dari penelitian yaitu inovasi.

Pendekatan tematik merupakan pendekatan yang menekankan pada tema yang mengintegrasikan beberapa topik pembelajaran. Pelaksanaan pembelajaran tematik integratif wajib menggunakan scientific approach. Scientific approach adalah pembelajaran yang melibatkan keterampilan proses yang meliputi, mengamati (observing), menanya (questioning), mengumpulkan informasi/mencoba (experimenting), menalar/mengasosiasi (associating) dan mengkomunikasikan (communicating) (Pangestika, 2018).

Media pembelajaran sangat dibutuhkan oleh guru dalam menyampaikan materi kepada siswa. Hal ini dikarenakan dalam sebuah pembelajaran pasti ada proses interaksi antara guru, siswa, dan bahan pembelajaran. Disinilah guru sangat membutuhkan media yang sesuai dengan kebutuhan siswa sebagai perantara dalam pembelajaran. Disamping itu, sifat anak usia SD yang cepat merasa bosan dan lelah dengan penyampaian materi secara verbal mengakibatkan materi yang dijelaskan oleh guru sulit diterima dan dipahami. Media pembelajaran dapat dimaknai sebagai alat yang membawa pesan dan informasi antara guru dan siswa. Penggunaan media dalam aktivitas pembelajaran dapat dilakukan baik secara individu maupun kelompok (Suryadi, 2020).

Kendala yang dialami oleh guru antara lain, siswa belum dapat beradaptasi dalam pembelajaran tematik integratif. Hal tersebut merupakan masalah yang terjadi di SDN Bekasi Jaya VIII. Siswa yang belum dapat beradaptasi dikarenakan pola pikir peserta didik yang masih terkotak-kotak untuk setiap mata pelajaran, sehingga guru merasa kesulitan dalam mengarahkan siswa ke pembelajaran tematik integratif. Kesulitan guru dalam mengarahkan siswa dalam pembelajaran juga terjadi pada saat guru mengajak siswa untuk aktif dalam proses pembelajaran seperti, berdiskusi dan mengungkapkan ide atau gagasan. Selain itu, siswa juga terbiasa hanya menerima informasi yang disampaikan oleh guru. Hal tersebut menjadi kesulitan bagi guru dalam melaksanakan pembelajaran mengaktifkan siswa. 
Pada penelitian sebelumnya terdapat Bahan ajar tematik integratif berbasis karakter ini menggunakan multimedia dimaksudkan untuk mengembangkan karakter siswa secara maksimal (Rahma, 2018) dan membantu meningkatkan minat belajar anak yang cenderung menyukai gambar sehingga proses belajar tidak terlalu membuat jenuh (Sahfitri \& Hartini, 2019). Kompetensi hasil belajar menggunakan Desain Pembelajaran Tematik Integratif Berbasis Pendekatan CTL lebih tinggi daripada Desain Pembelajaran Tematik Integratif rancangan dari Pemerintah dengan hasil taraf kepercayaan 0.05 maka diperoleh hasil a lebih kecil dari 0,05 (Saputri \& Mawardi, 2018). Aktivitas guru sebelum dan ketika menggunakan produk meningkat sebesar 34,25\%. Aktivitas siswa sebelum dan ketika produk diterapkan meningkat 38,89\% (Abduh, 2015). Berdasarkan penilaian ahli materi Sangat Baik (VG) dengan skor rata-rata 65 (Yuliawati, 2017). Uji coba kelompok kecil memperoleh presentasi sebesar 92\% dengan kualifikasi sangat layak, dan uji coba kelompok besar mendapatkan presentasi nilai sebanyak $91 \%$ dengan kualifikasi sangat layak (Purnamasari, 2018).

Pelaksanaan pembelajaran tematik-integratif dengan pendekatan scientific approach perlu menggunakan media pembelajaran yang dapat mendukung keberhasilan pembelajaran yang disesuaikan dengan perkembangan cara belajar peserta didik, sehingga tujuan dari pemcapaian kompetensi inti, kompetensi dasar, dan indikator pembelajaran tematik integratif dapat tercapai. Berdasarkan pemilihan media pembelajaran tersebut, secara spesifik peneliti menggunakan media pembelajaran berbasis Teknologi Informasi (TI) (Wibawanto, 2017).

Materi-materi yang termuat dalam buku pegangan banyak yang membutuhkan visualisasi yang lebih nyata, bukan hanya dengan teks dan gambar. Oleh karena itu, perlu alat bantu untuk mendukung proses pembelajaran sehingga pembelajaran menjadi efektif, menarik dan menyenangkan. Salah satu alat pendukung pembelajarannya yaitu media pembelajaran, khususnya multimedia Karena multimedia merupakan media yang memuat lebih dari satu jenis media dan dapat mengaktifkan siswa. Hal ini dikarenakan siswa sendiri yang mengoperasikan media pembelajaran tetapi tetap dalam pengawasan guru.

Berdasarkan permasalahan yang ada, guru kelas II pada SDN Bekasi Jaya VIII sangat membutuhkan media pembelajaran. Media pembelajaran yang dibutuhkan khususnya adalah multimedia untuk satu tahun pembelajaran. Melalui media pembelajaran ini, materi-materi yang dianggap sulit disampaikan atau tidak terjangkau oleh guru dapat divisualisasikan sehingga lebih menarik perhatian siswa dalam pembelajaran. Dengan demikian, siswa tidak hanya membayangkan segala sesuatu yang sedang dipelajarinya, namun dapat mengamati bentuk aslinya dari materi yang dipelajari. Media pembelajaran tersebut dipakai guru untuk mempermudah penyampaian materi dalam pembelajaran tematik interaktif yang berbasis scientific approach.

Dalam perancangan media pembelajaran ini menggunakan bahasa ActionScript 3.0 pada Adobe Flash CS6, hal ini disebabkan karena AcitonScript 3.0 merupakan bahasa pemograman yang sudah banyak penggunanya dan selain itu juga mudah penggunannya. Dengan ini penulis menggunakan Actionscript 3.0 agar penelitian selanjutnya menggunakan 
bahasa pemograman yang sama dan dapat dengan mudah melanjutkan penilitian. Pada pembuatan penelitian ini penulis akan menggunakan metode Analysis, Design, Development, Implementation and Evaluate (ADDIE).

\section{Metode Penelitian}

Model Pengembangan dan kerangka pemikiran dijabarkan pada pembahasan metode penelitian. Pembahasan model pengembangan menjelaskan mengenai pembuatan media pembelajaran tematik integratif dengan pendekatan ilmiah scientific approach untuk siswa kelas II sekolah dasar yang dapat digunakan untuk mendukung proses belajar dan mengajar di dalam kelas. Teknik pengumpulan data yang penulis gunakan dalam penulisan ini yaitu: Pertama, Observasi; Peninjauan langsung kelapangan dengan melakukan pengamatan tanpa adanya interupsi proses ataupun aktivitas yang ada. Kedua, Wawancara; kegiatan pengumpulan data yang dilakukan dengan cara mengajukan pertanyaan-pertanyaan yang berhubungan dengan aktivitas saat ini sistem informasi seperti apa yang diharapkan. Wawancara memiliki keunggulan dimana sifatnya yang lebih personal bisa membuat narasumber lebih terbuka. Ketiga, Studi Pustaka; Teknik dilakukan dengan cara mempelajari dan mengumpulkan informasi melalui bukubuku literatur, jurnal dan prosiding yang berkaitan dengan penelitian pada siswa kelas II SDN Bekasi Jaya VII. Pengembangan perangkat lunak untuk Implementasi dalam penelitian ini menggunakan metode Analysis-Design-Develop-Implement-Evaluate (ADDIE)

Tahap analisis menjawab pertanyaan tentang siapa yang akan menggunakan sistem, apa yang akan dilakukan sistem, serta kapan dan dimana sistem akan digunakan. Dari proses analisa dapat disimpulkan bahwa siswa kelas II SDN Bekasi Jaya VIII membutuhkan sebuah media pembelajaran yang dapat membantu proses pembelajaran tematik integratif. Pada tahap design akan dilakukannya perancangan tampilan berupa storyboard yang akan dibuat dalam media pembelajaran tematik integratif yang tentunya mudah untuk digunakan oleh siswa dan guru dalam proses belajar mengajar di sekolah. Pada tahap development mulai dilakukannya realisasi rancangan yang telah dibuat pada tahap desain sebelumnya. Media pembelajaran ini nantinya akan dibuat dengan menggunakan Adobe Flash dan dengan menggunakan bahasa perograman ActionScript 3.0. Pada tahap implementasi ini meliputi penerapan spesifikasi perangkat keras, dan perangkat lunak yang digunakan untuk menjalankan media pembelajaran yang telah selesai dibuat dan akan di implementasikan kegunaannya dalam proses pembelajaran di dalam kelas dan tentunya para siswa akan tetap didampingi oleh wali kelas dalam penggunaan media pembelajaran ini. Pada tahap terakhir ini dilakukanlah proses pendukung evaluasi dari media pembelajaran yang telah dibuat untuk melakukan proses pengembangan atau penambahan fitur yang belum ada pada sofware tersebut. Tahap ini sangat penting ketika software yang dijalankan ditemukan kesalahan yang tidak ditemukan pada proses sebelumnya. Pada tahap ini akan di lakukaaan dengan adanya dokumen masukan yang nantinya akan penulis dapat dari wali kelas II SDN Bekasi Jaya VIII dari haris belajar para siswa selama satu tahun pembelajaran setelah adanya media pembelajaran ini. Dari dokumen 
masukan itu nantinya akan diketahui kebermanfaatan media pembelaaran untuk proses pembelajaran di kelas untuk menghasilkan validitas aplikasi yang baik. Dan dengan adanya dokumen masukan tersebut nantinya akan diketahui apakah media pembelajaran yang dibuat sangat membantu proses belajar mengajar di SDN Bekasi Jaya VIII.

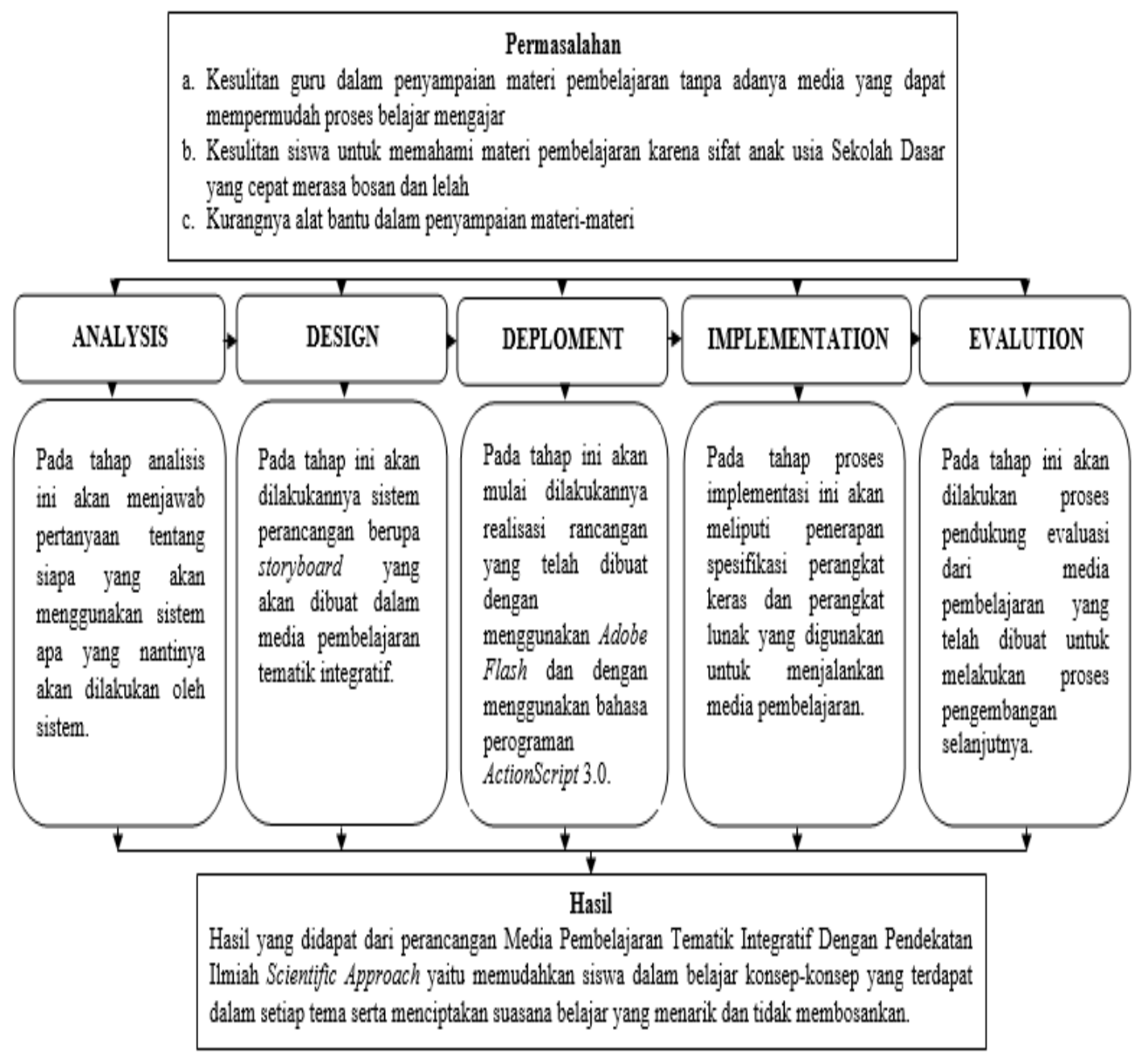

Sumber: Hasil Penelitian (2020)

Gambar 1. Kerangka Media Pembelajaran Tematik Integratif Dengan Pendekatan IImiah Scientific Approach Untuk Siswa Kelas II Sekolah Dasar

\section{Hasil dan Pembahasan}

Pada tahap ini akan di jelaskan hasil dan pembahasan dari media pembelajaran tematik integratif yang telah di buat menggunakan Adobe Flash CS6 dan menggunakan bahasa pemrograman ActionScript 3.0 dengan metode ADDIE. Pembahasan dibagi menjadi 3 tahapan yaitu, proses bisnis sistem, desain dan Implementasi program.

\subsection{Proses Bisnis Sistem}

Dalam proses bisnis ini menjelaskan prosedur tentang sistem berjalan yang sudah di terapkan maupun yang nantinya akan berjalan pada media pembelajaran yang akan dibuat untuk siswa kelas II pada SDN Bekasi Jaya VIII. 


\section{Proses Belajar Mengajar}

Dalam pelaksanaan pembelajaran siswa kelas II sekolah dasar pada SDN Bekasi Jaya VIII sudah mengikuti kurikulum 2013 yaitu pembelajaran selama satu tahun menggunakan buku tematik, dimana pada pembelajaran tematik ini pada dasarnya adalah model pembelajaran terpadu yang menggunakan tema untuk mengaitkan beberapa mata pelajaran sehingga dapat memberikan pengalaman bermakna bagi siswa. Materi yang diajar guru dari buku paket tematik yang telah mengikuti kurikulum 2013 sebagai standar pembelajaran.

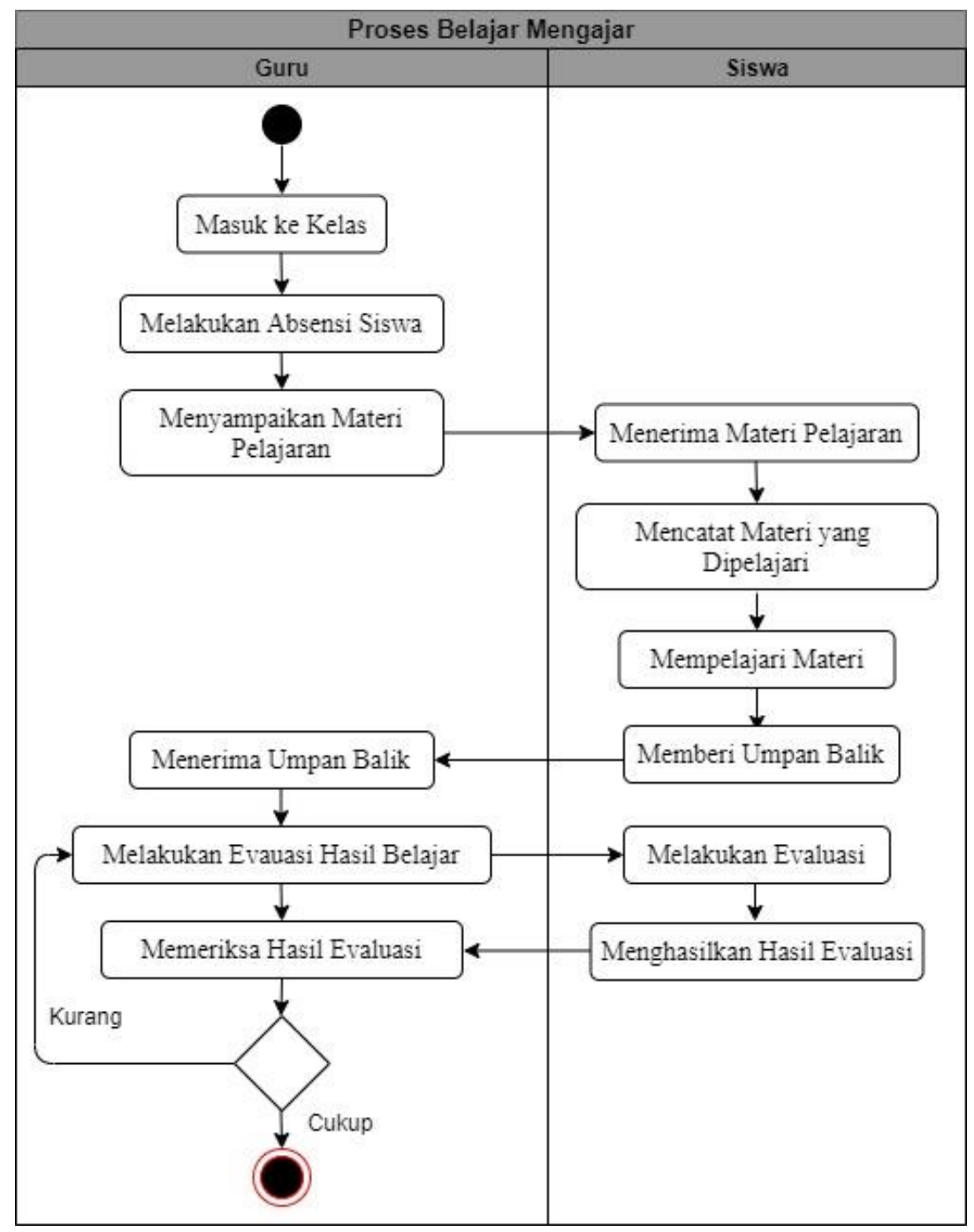

Sumber: Hasil Penelitian (2020)

Gambar 2. Proses Bisnis Sistem Tematik Integratif Pendekatan IImiah Scientific Approach

Gambar 2 merupakan penggambaran dari proses pembelajaran guru dengan siswanya.

Pada proses pembelajaran di dalam kelas perama siswa masuk kedalam ruang kelas sesuai dengan waktu yang telah di tentukan oleh sekolah yaitu pukul 7 pagi, kemudin pada awal pembelajaran guru akan melakukan absensi kehadiran terhadap semua siswa, setelah dilakukannya absensi kemudian guru akan menyampaikan materi yang diajarkan sesuai dengan kompetensi dasar dan indikator yang ada pada silabus pembelajaran. Guru akan menjelaskan materi yang ada pada buku paket tematik dan evaluasi pembelajaran dilakukan 
dengan memberikan soal latihan untuk dikerjakan di sekolah dan soal latihan untuk siswa kerjakan dirumah kemudian ada pula beberapa materi yang proses evaluasinya dilakukan secara praktek langsung di sekolah. Dari hasil evaluasi yang dilakukan guru kepada siswa nantinya guru akan melihat dan menilai apakah siswa sudah mengerti terhadap materi yang telah diajarkan, setelah itu guru dapat mengevaluasi ulang materi yang belum siswa pahami. Dalam evaluasi menyeluruh selama periode tertentu sekolah mengadakan Ulangan Tengah Semester sebagai penilaian siswa setiap pertengahan semester pembelajaran dan kemudian akan dilakukannya Ulangan Akhir Semester sebagai penanda penilaian akhir Siswa dalam semester yang ditempuh.

\subsection{Desain}

Pada tahap ini perancangan media pembelajaran yang dibuat untuk menyelesaikan masalah yang dialami guru dan siswa selama ini di SDN Bekasi Jaya VIII. Tahapan ini terdiri dari perancangan proses (Use Case Diagram, Scenario Use Case Diagram, Activity Diagram, Sequence Diagram dan Rancangan Storyboard). Dalam pembuatan animasi interaktif, use case diagram diperlukan untuk menjelaskan interaksi antara Siswa sebagai aktor dengan software nya yaitu animasi interaktif yang dibuat secara sederhana disertai dengan penjelasan disetiap menu yang akan digunakan oleh Siswa.

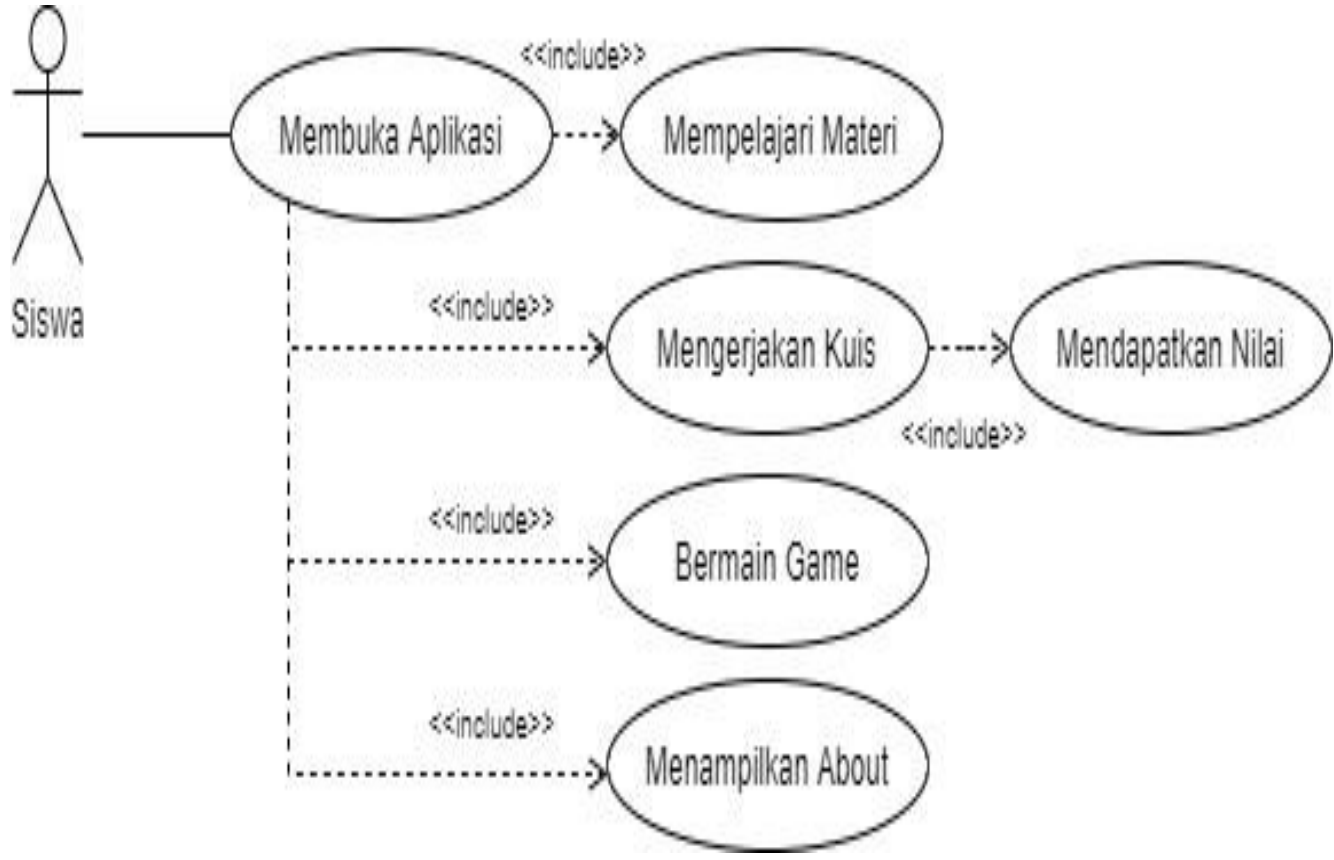

Sumber: Hasil Penelitian (2020)

Gambar 3. Use Case Diagram Media Pebelajaran Tematik Integratif dengan Pendekatan IImiah Scientific Aprooach untuk Siswa Kelas II Sekolah Dasar

Selanjutnya pada storyboard dalam menu materi terdapat 8 button yang dapat diakses akan tetapi sebelum memilih menu materi terlebih dahulu ke halaman utama kemudian pilih menu materi. Materi tersebut disajikan berdasarkan kurikulum pembelajaran tematik 8 . Pada menu materi juga terdapat 4 (empat) subtema dan yang terakhir. 
Tabel 1. Storyboard Menu Materi

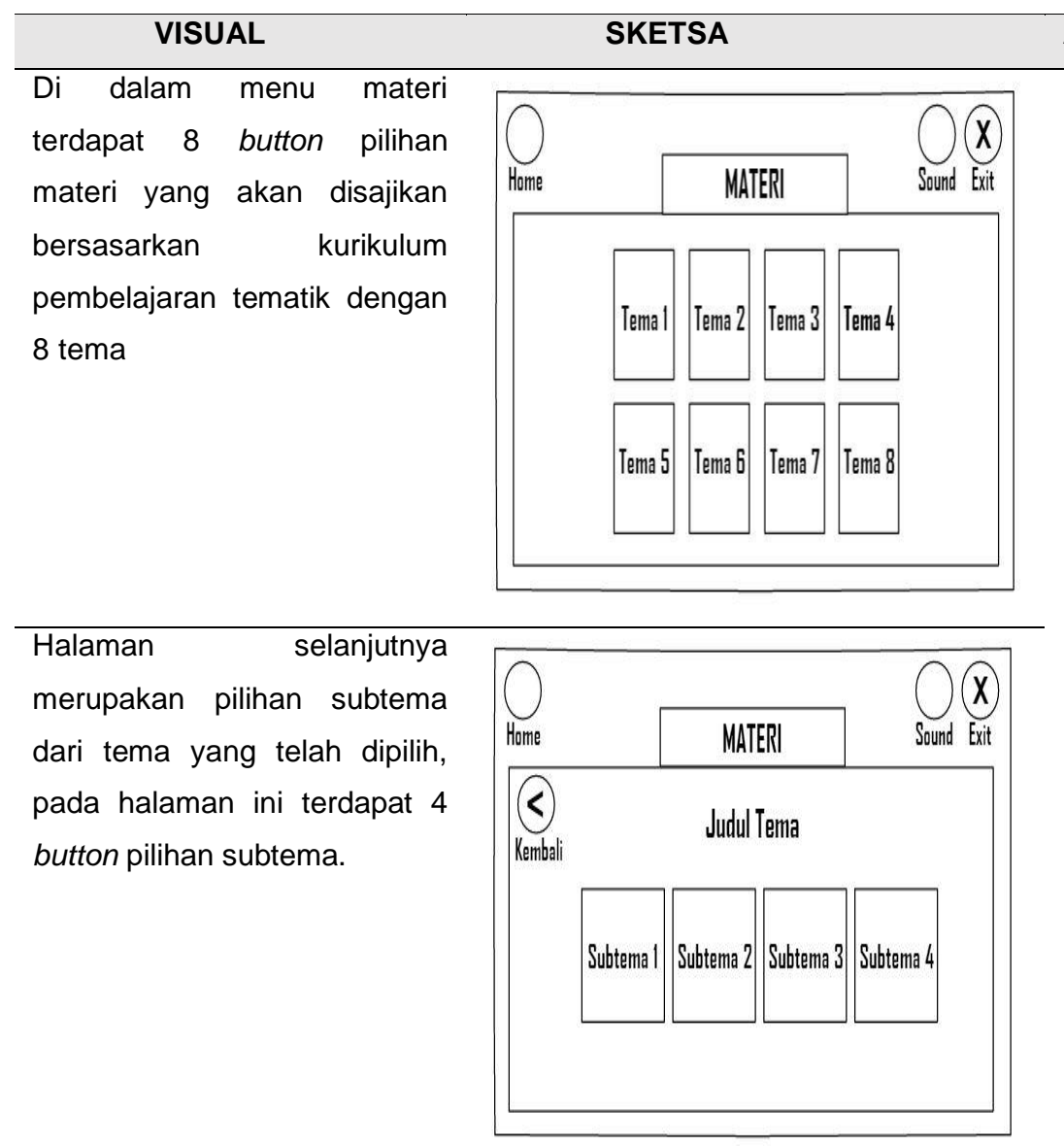

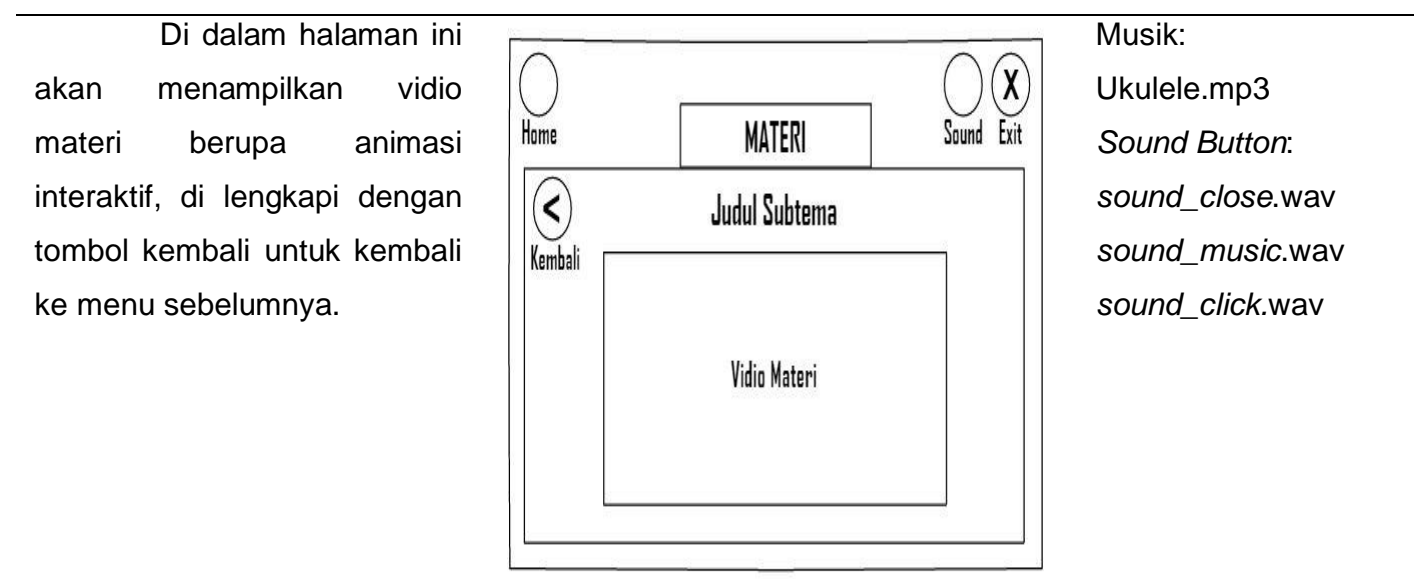

Sumber: Hasil Penelitian (2020)

\subsection{Implementasi Program}

Pada tahapan ini penulis menjabarkan tentang implementasi program yang telah dibuat dengan menggunakan Adobe Flash dan bahasa Action Script 3.0 agar mempunyai tujuan yang sesuai dengan keinginan.

Pada saat pertama kali dijalankan tampak tampilan utama button untuk memulai, seperti pada Gambar 4. 


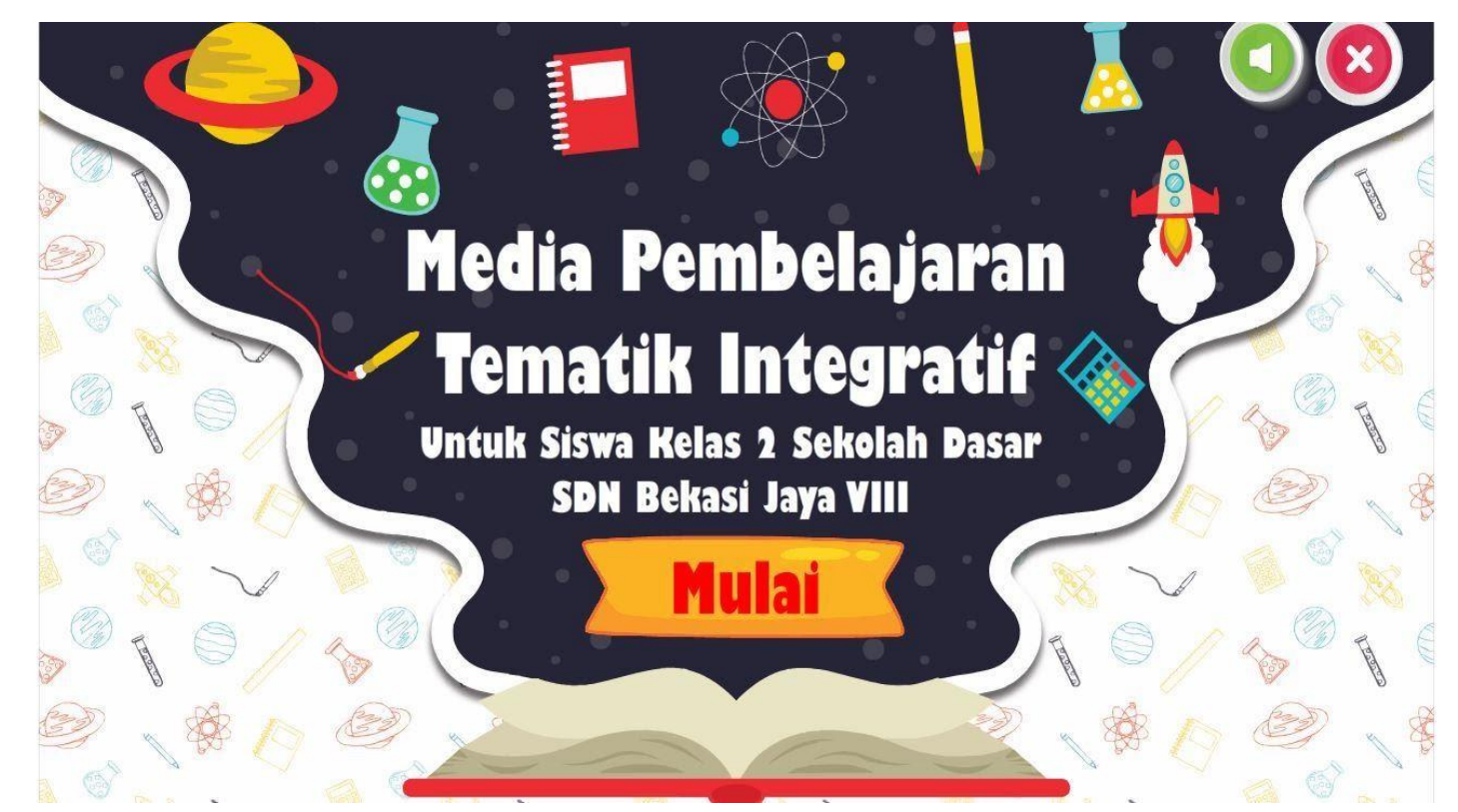

Sumber: Hasil Penelitian (2020)

\section{Gambar 4. Halaman Awal}

Setelah itu akan menuju kehalaman Menu utama. Menu utama merupakan halaman yang berisi tombol-tombol dari menu yang ada didalam program ini. Menu-menu yang ada yaitu, menu materi, menu kuis, menu games dan menu about terlihat pada Gambar 5.

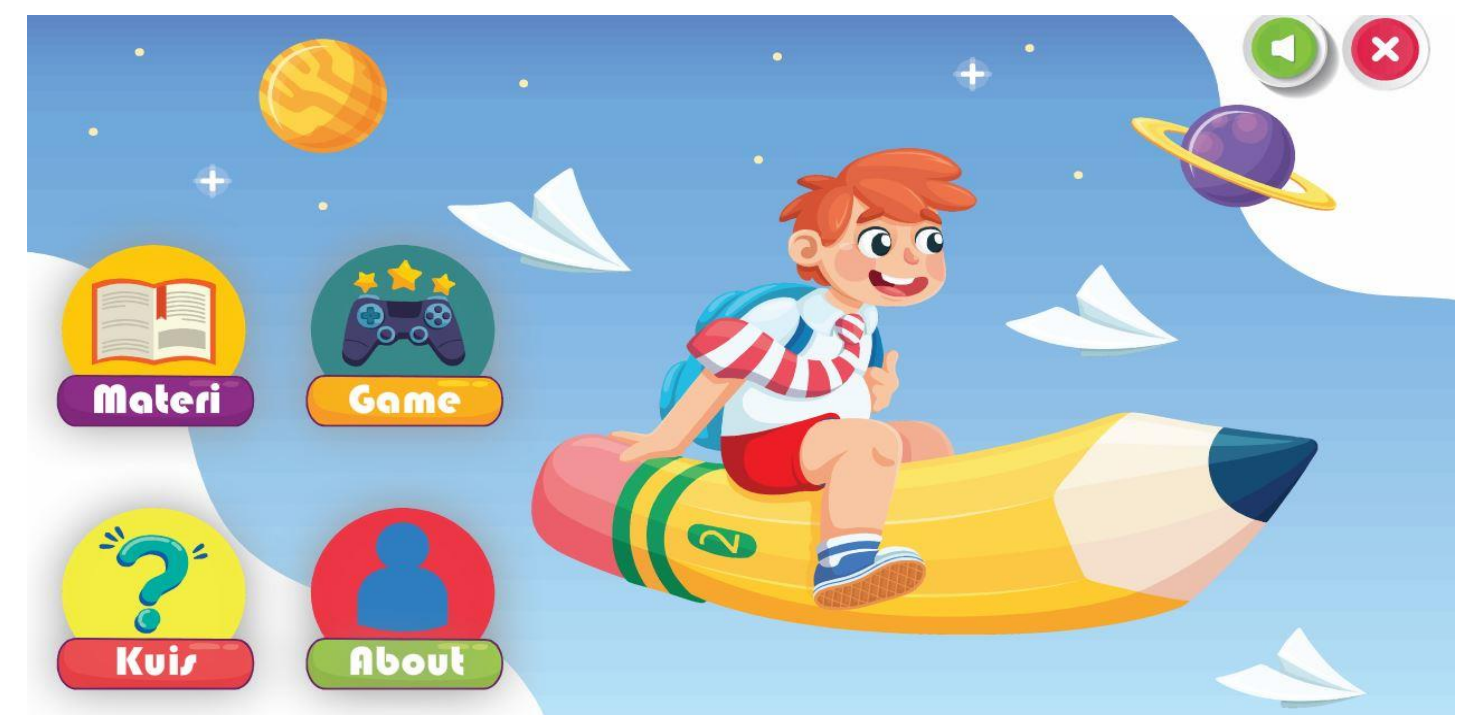

Sumber: Hasil Penelitian (2020)

Gambar 5. Halaman Menu Utama

Menu materi adalah halaman yang berisi tombol-tombol yang menampilkan materi didalamnya, yaitu interval nada, daftar pencipta lagu nasional dan daftar lagu nasional. Pada halaman ini akan berisikan pilihan tema pembelajaran yang sesuai dengan kurikulun 2013. Terdapat 8 tema pembelajaran yang akan dipelajari dalam satu tahun pembelajaran. Siswa 
maupun guru dapat memilih tema yang akan dipelajari pada saat di kelas disajikan pada gambar 6 .

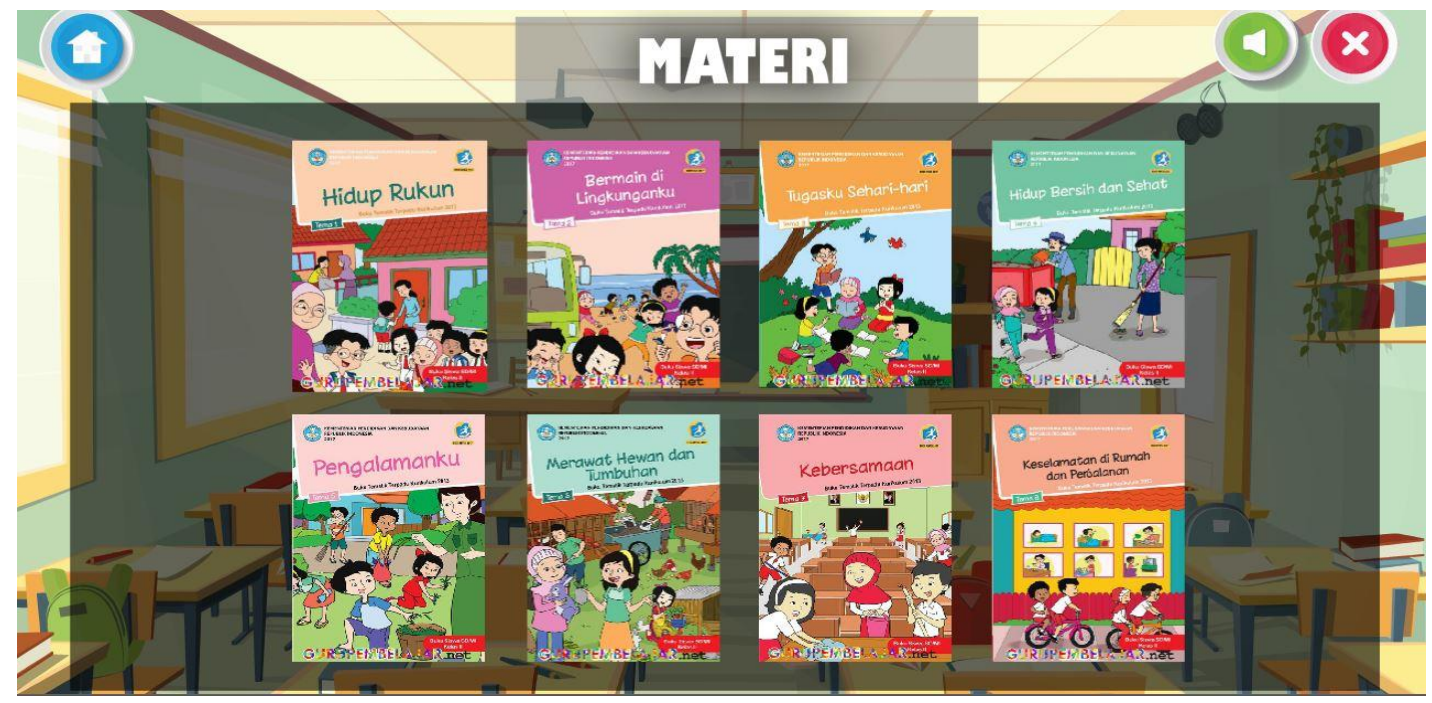

Sumber: Hasil Penelitian (2020)

Gambar 6. Halaman Menu Materi

Gambar 7 merupakan halaman menu materi terdapat subtema yang berisikan pilihan subtema materi yang terdapat dalam sebuah buku tema, dalam satu buku tema terdiri dari 4 subtema yang berisikan materi pemelajaran yang akan di pelajari oleh siswa. Siswa maupun guru dapat memilih subtema yang akan dipelajari di dalam kelas.

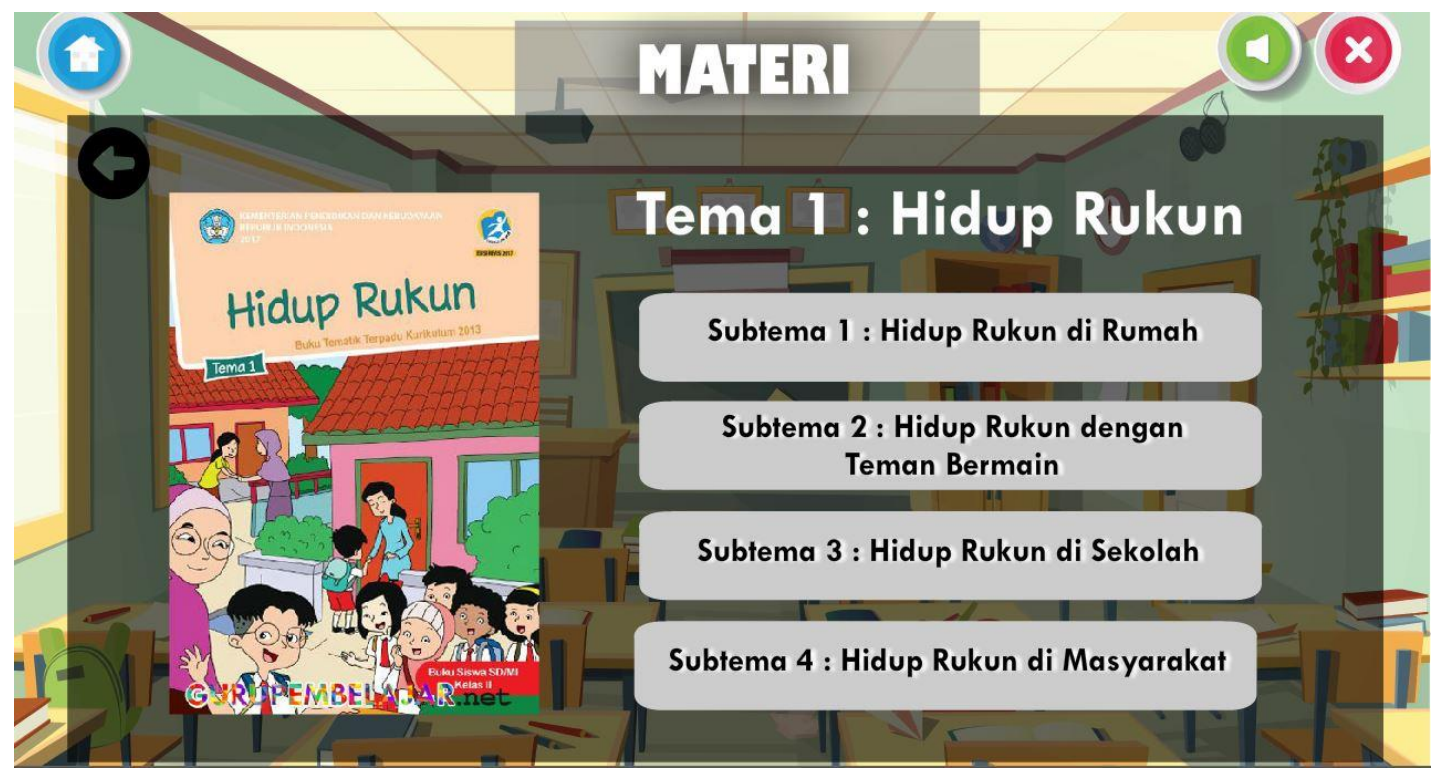

Sumber: Hasil Penelitian (2020)

Gambar 7. Halaman Subtema Menu Materi

Terdapat video pembelajaran yang sesuai dengan materi yang akan di pelajari pada suatu tema dalam buku tematik yang akan memudahkan para siswa untuk memahami materi karena pembahasan dikemas dalam bentuk animasi interaktif yang mudah di pahami dan menyenangkan, seperti ditunjukkan pada Gambar 8. 


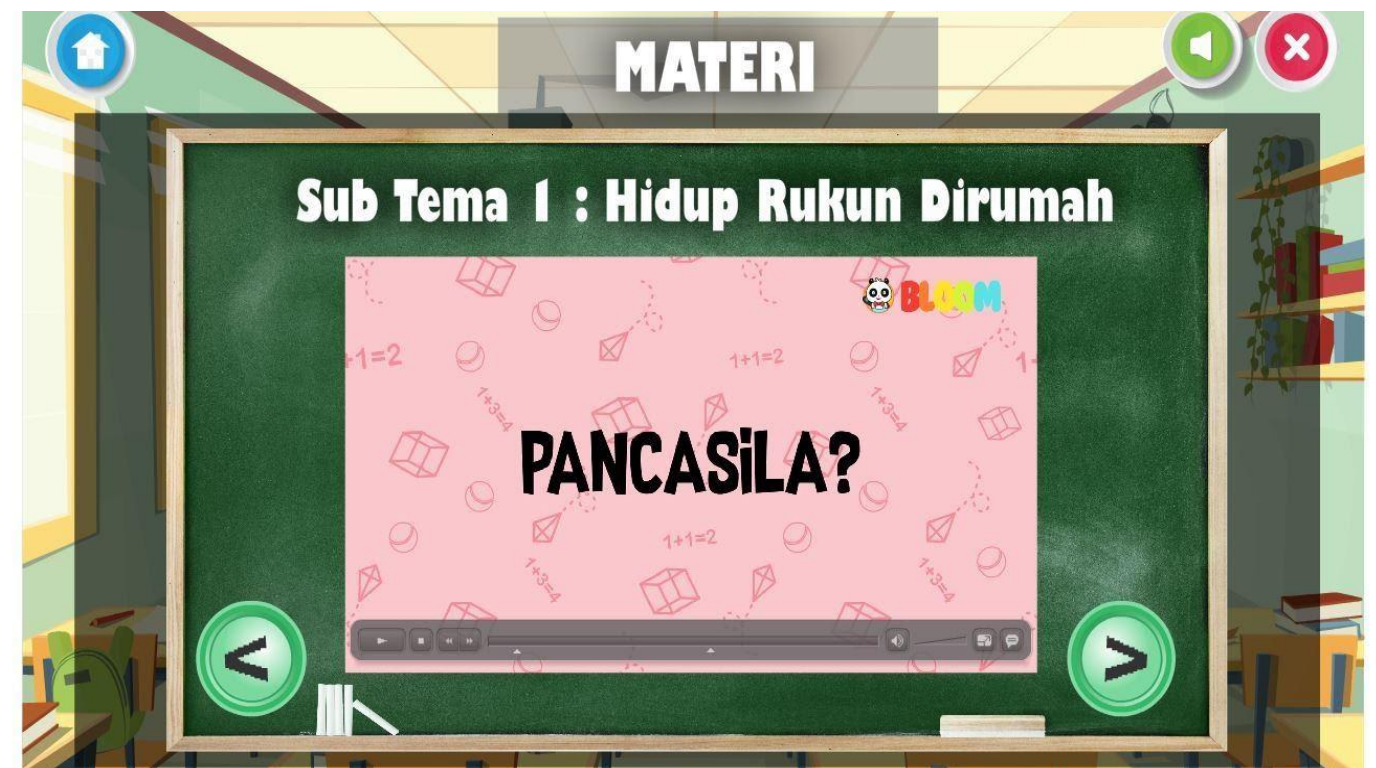

Sumber: Hasil Penelitian (2020)

Gambar 8. Halaman Video Pembelajaran

Halaman kuis menampilkan soal kuis yang harus di jawab oleh siswa, setiap jawaban yang dijawab akan mendapatkan skor dari nilai benar atau salah bersasarkan jawaban yang telah dipilih oleh siswa, seperti pada Gambar 9.

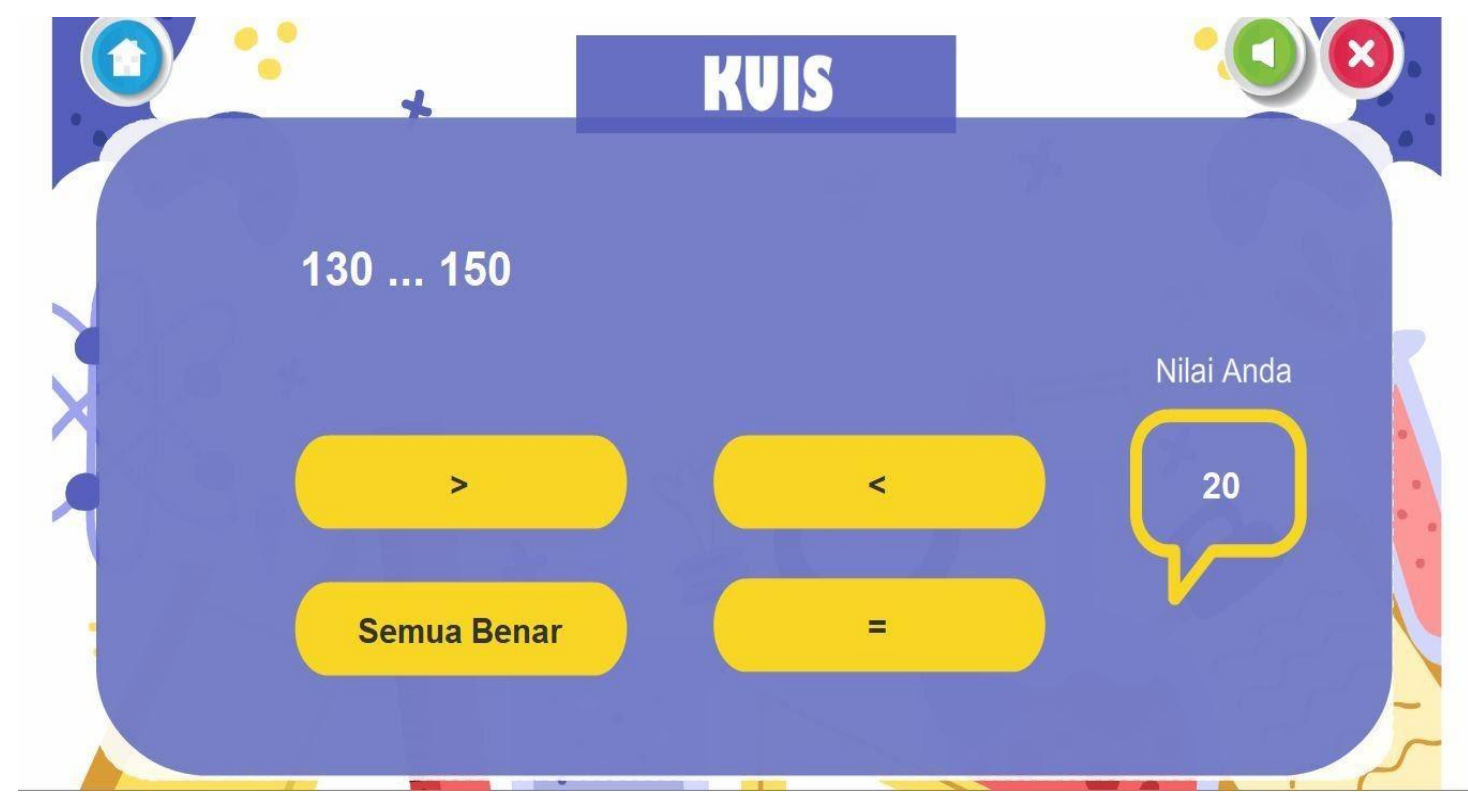

Sumber: Hasil Penelitian (2020)

\section{Gambar 9. Halaman Kuis}

Menu games yang terdapat 2 jenis games yang dapat dimainkan oleh siswa agar siswa tidak merasa bosan saat belajar. Games yang dibuat merupakan games edukasi yang dapat mengasah sejauh mana siswa sudah mengerti tentang materi yang sudah diajarkan pada media pembelajaran ini. Gambar 10 menunjukkan tampilan game puzzle. 


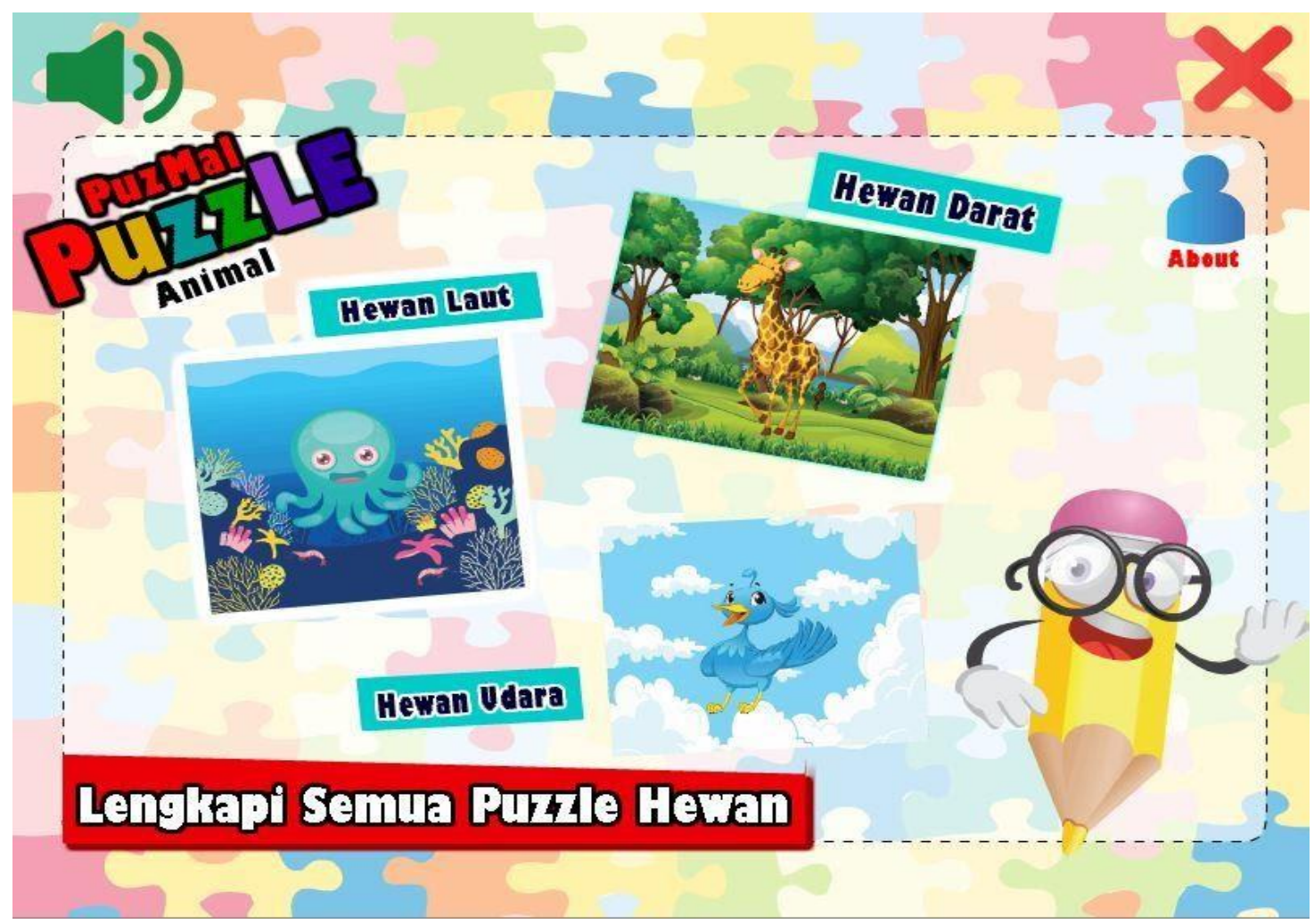

Sumber: Hasil Penelitian (2020)

Gambar 10. Halaman Game Puzzle

Gambar 10 menunjukkan tampilan game maze dalam media pembelajaran.

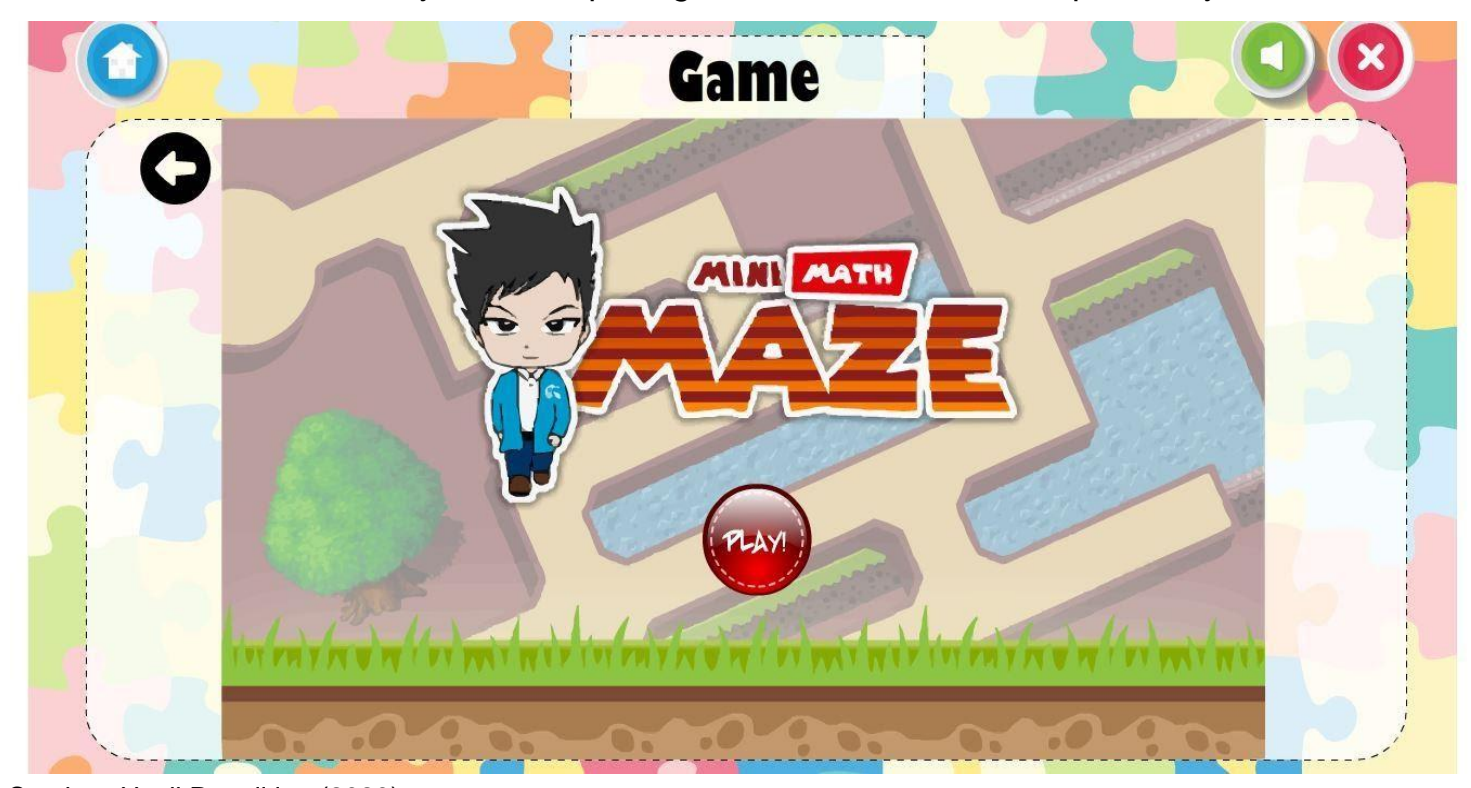

Sumber: Hasil Penelitian (2020)

Gambar 11. Game Maze

\section{Kesimpulan}

Setelah melakukan penelitian di SDN Bekasi Jaya VIII pada pembelajaran tematik integratif untuk siswa kelas II, maka dihasilkan sebuah Media Pembelajaran Tematik Integratif 
dengan Pendekatan IImiah Scientific Approach yang dapat dijalankan menggunakan platform Android. Media pembelajaran ini dibuat sesuai dengan kebijaksanaan dari pihak sekolah untuk membantu guru dalam menyampaikan materi yang akan disampaikan dan dijelaskan kepada siswa yang belajar di sekolah tersebut. Setelah penelitian tersebut, maka dapat disimpulkan bahwa dengan adanya Media Pembelajaran Tematik Integratif dengan Pendekatan IImiah Scientific Approach untuk Siswa kelas II Sekolah Dasar ini siswa dapat memahami materi yang diajarkan dengan mudah. Dengan adanya Media Pembelajaran Tematik Integratif dengan Pendekatan IImiah Scientific Approach untuk Siswa kelas II Sekolah Dasar ini guru dapat menciptakan suasana mengajar yang lebih mudah dan menyenangkan. Dan dengan adanya materi yang dibuat animasi sedemikian rupa dapat menarik pehatian siswa dalam memahami setiap materi yang diajarkan dan siswa tidak akan merasa bosan saat belajar karena setiap materi telah dikemas dalam bentuk animasi interakif yang menarik.

\section{Daftar Pustaka}

Abduh, M. (2015). Pengembangan Media Pembelajaran Tematik-Integratif Berbasis Sosiokultural bagi Siswa Kelas IV Sekolah Dasar. Profesi Pendidikan Dasar, 2(2), 121132. https://www.researchgate.net/publication/296704617

Anwar, S., Schadaw, F. E., \& Althafani, A. (2018). Perancangan Animasi Interaktif Pengenalan Bahasa Sunda Untuk Anak - Anak Metode Addie. Jurnal IImu Pengetahuan Dan Teknologi Komputer, 3(2), 195-102.

Pangestika, R. R. (2018). Pengembangan Multimedia Interaktif Adobe FlashÂ® pada Pembelajaran Tematik Integratif Berbasis Scientific Approach Subtema Keindahan Alam Negeriku. KEGURU" Jurnal IImu Pendidikan Dasar", 2(1), 93-106.

Purnamasari, N. L. (2018). Metode Addie Pada Pengembangan Media Interaktif Adobe Flash Pada Mata Pelajaran Tik. Jurnal Pena Sd, 05(1), 23-31.

Rahma, F. I. (2018). Pengembangan Bahan Ajar Tematik Integratif Berbasis Karakter Dengan Multimedia Interaktif Kelas IV di SDI Wahid Hasyim Bangil. Pancawahana: Jurnal Studi Islam, 13(1), 91-95.

Sahfitri, A., \& Hartini, S. (2019). Metode ADDIE Pada Aplikasi Interaktif Mengenal Bagian Tubuh Manusia Dua Bahasa Untuk Anak Sekolah Dasar. Information System For Educators And Professionals, $\quad 3(2), \quad 141-152 . \quad$ http://ejournalbinainsani.ac.id/index.php/ISBI/article/view/1085/955

Saputri, W. A. T., \& Mawardi, M. (2018). Pengembangan Desain Pembelajaran Tematik Integratif Berbasis Pendekatan Contextual Teaching and Learning (Ctl) Kelas 4 Sekolah $\begin{array}{lllll}\text { Dasar. Jurnal IImiah Pendidikan } & \text { Dasar, }\end{array}$ https://doi.org/10.30659/pendas.4.2.104-114

Suryadi, A. (2020). Teknologi dan Media Pembelajaran Jilid 2. CV. Jejak.

Wibawanto, W. (2017). Desain dan Pemrograman Multimedia Pembelajaran Interaktif. Penerbit Cerdas Ulet Kreatif. 
Yuliawati, F. (2017). Pengembangan Media Pembelajaran Berbasis Adobe Flash CS3 Professional dalam Pembelajaran IPA Berbasis Integrasi Islam-Sains di SD/MI Kelas 5. Trihayu: Jurnal Pendidikan Ke-SD-An, 3(3), 129-138. http://jurnal.ustjogja.ac.id/index.php/trihayu/article/view/1874/1043 